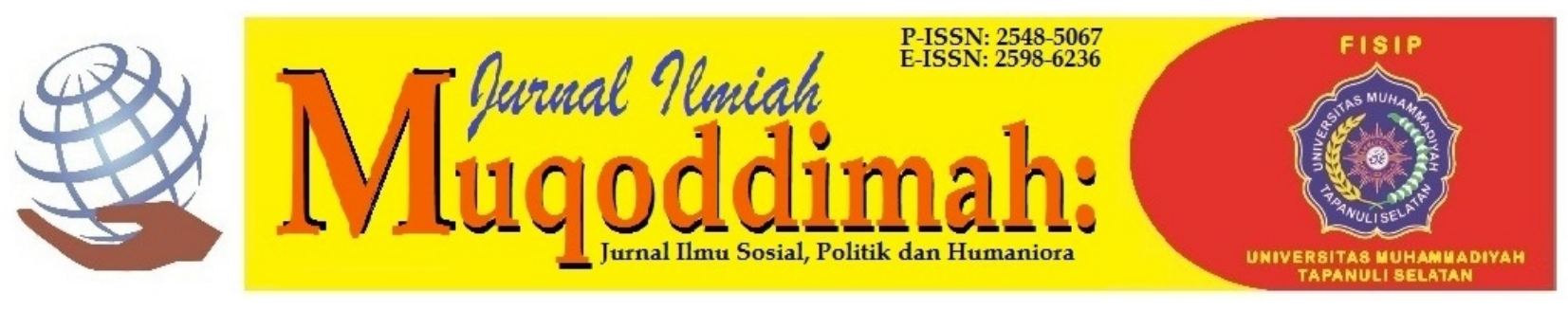

\title{
Sosialisasi Kebijakan Pemerintah Provinsi Bali Melalui Perspektif Komunikasi Pembangunan
}

\author{
Putu Ika Astiti Tajem ${ }^{1}$, I Nyoman Subanda2) \\ Magister Administrasi Publik, Universitas Pendidikan Nasional Denpasar, Indonesia1) \\ Universitas Pendidikan Nasional Denpasar, Indonesia ${ }^{2)}$ \\ ikatajem@gmail.com1) \\ subanda.nyoman@yahoo.co.id2)
}

\begin{abstract}
Abstrak
Pada saat ini, Bali mengalami musibah dengan penularan pandemi COVID-19. Berdasarkan data Peta Penyebaran Covid-19 dari Tim SPBE Provinsi Bali. Untuk mencegah penularan Covid-19 lebih luas di Bali. Pemerintah Provinsi Bali mengeluarkan Pergub No.15 Tahun 2020 mengenai Paket Kebijakan Percepatan Penanganan Corona Virus Disease 2019 (Covid-19) di Provinsi Bali. Pihak Gugus Tugas menerapkan beberapa syarat medis seperti surat keterangan negatif rapid tes Covid-19 untuk memasuki wilayah Provinsi Bali. Pemeriksaan para pelaku perjalanan juga dibantu oleh Satgas Gotong Royong yang ada di masing - masing desa adat yang dibantu aplikasi Cek Diri yang berbasis Desa Adat. Sosialisasi dari aplikasi. Metode penelitian ini menggunakan pendekatan kualitatif dengan lokasi penelitian pada Dinas Komunikasi, Informatika dan Statistik Pemerintah Provinsi Bali. Hasil penelitian menunjukan strategi komunikasi yang dilaksanakan dalam sosialisasi aplikasi Cek Diri dilakukan dengan sosialisasi di lapangan bertempat di Bandara Internasional I Gusti Ngurah Rai dan Pelabuhan Gilimanuk atau Padang Bay. Serta menyebarkan pesan dalam berbagai bentuk yang disesuaikan dengan media yang digunakan.
\end{abstract}

Kata kunci: Aplikasi Cek Diri, Covid-19, Komunikasi, Sosialisasi Kebijakan

\begin{abstract}
At this time, Bali is experiencing a disaster with the transmission of the COVID-19 pandemic. Based on the Covid-19 Spread Map data from the Bali Province SPBE Team. To prevent the spread of Covid-19 more widely in Bali. The Bali Provincial Government issued Governor Regulation No. 15 of 2020 regarding the Policy Package for the Acceleration of Handling Corona Virus Disease 2019 (Covid-19) in the Province of Bali. The Task Force has implemented several medical conditions, such as a negative certificate for the Covid-19 rapid test to enter the Bali Province area. The inspection of travellers is also assisted by the Gotong Royong Task Force in each traditional village who is assisted by the Self-Check application based on the Traditional Village. Socialization of the application. This research method uses a qualitative approach with the research location at the Department of Communication, Information and Statistics of the Provincial Government of Bali. The results showed that the communication strategy implemented in the socialization of the Self-Check application was carried out by outreach in the field at I Gusti Ngurah Rai International Airport and Gilimanuk Harbor or Padang Bay. And spread the message in various forms that are adapted to the media used.
\end{abstract}

Keywords: Self Check Application, Covid-19, Communication, Policy Socialization 
JURNAL ILMIAH MUQODDIMAH: Jurnal Ilmu Sosial, Politik Dan Humaniora E-ISSN : 2598-6236

http://jurnal.um-tapsel.ac.id/index.php/muqoddimah
Sosialisasi Kebijakan Pemerintah Provinsi Bali Melalui Perspektif Komunikasi Pembangunan.

(Putu Ika Astiti Tajem, I Nyoman Subanda)

\section{PENDAHULUAN}

Pada saat ini, masyarakat di Bali sedang mengalami pergeseran sosial. Perkembangan informasi dan ekonomi memberikan dampak perubahan yaitu semakin berkurangnya apresiasi terhadap nlai-nilai budaya lokal dan melahirkan gaya hidup yang indivualisme.

Metamorfosis ini dapat terbetuk dari akulturasi budaya yang sudah ada di Bali. para pelaku perjalanan membawa masuk budaya mereka ke Bali. Sehingga terdapat kultur baru yang tumbuh di Bali. Penyeragaman dan neoliberalisasi pada aspek kehidupan khususnya kearifan lokal yang selama ini menjadi pedoman masyarakat di Bali. Hal ini memberikan spirit budaya dalam beragama masyarakat Bali lebih menjunjung nilai global dengan mengesampingkan nilai trandisional. Dampaknya terjadi berbagai bentuk perubahan nilai moral yang diamati dalam corak budaya, gaya dan pola hidup masyarakat. Karena itu perlu dikembangkan kearifan lokal Bali yang dilakukan secara optimal pada generasi muda Bali saat ini. (Suwardani, 2015)

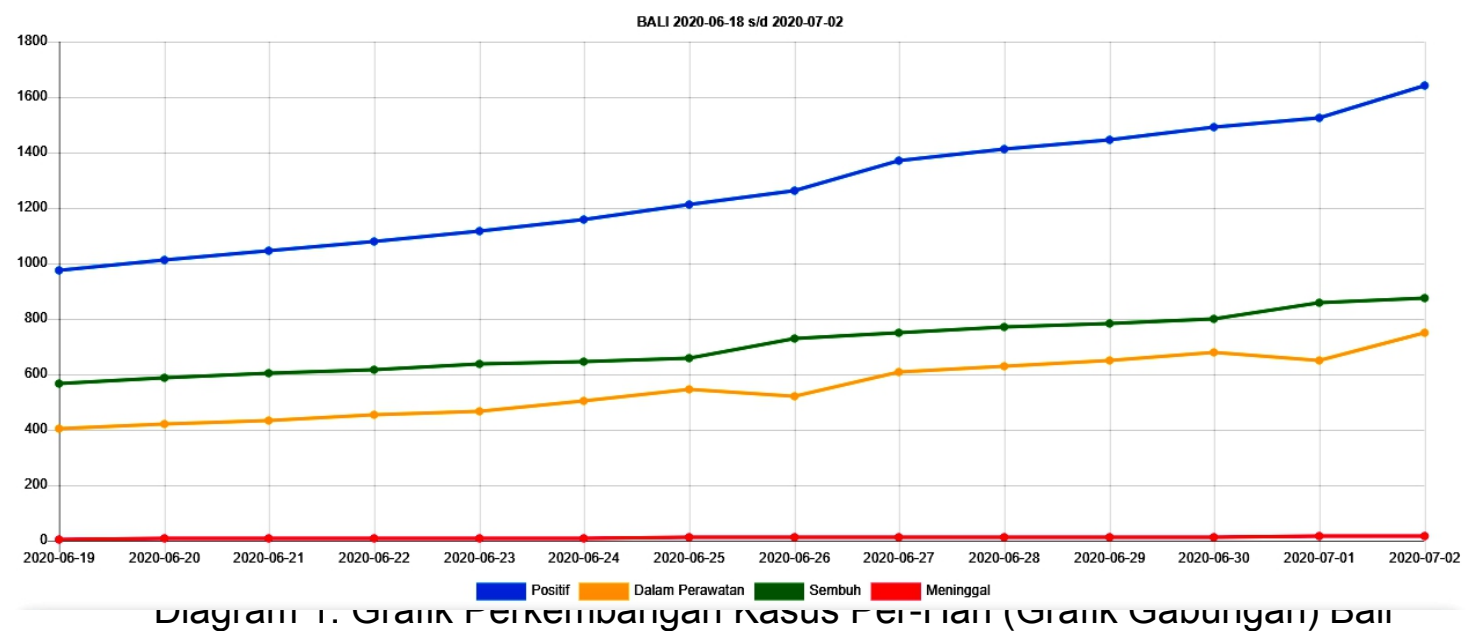

Dengan adanya keingintahuan masyarakat Bali tentang program dan kebijakan terbaru pemerintah. Masyarakat Bali yang sudah melek tekhnologi. Maka Pemerintah Provinsi Bali berupaya untuk mensosialisasikan seluruh program kerja dan kebijakan pemerintah kepada masyarakat yang salah satunya melalui media. Baik media cetak, elektronik dan online. Program pemerintah Provinsi Bali ini masih terbilang baru sehingga masyarakat masih kurang mengetahui apa saja program-program dan kebijakan pemerintah yang sudah berjalan maupun akan dikembangkan.

Media merupakan salah satu cara mempermudah Pemerintah Provinsi Bali mensosialisasikan seluruh program kerja dan kebijakan publiknya. Media diharapkan dapat menjadi penyelaras yang dapat memberikan berita - berita yang teraktual dan terpercaya yang bisa di jadikan acuan dan dapat dipercaya oleh masyarakata luas. Bagi pemerintah, untuk memperoleh citra di masyarakat senantiasa berkaitan dengan program tujuan dalam rangka pembangunan yang telah dilakukan oleh pemerintahan tersebut. Untuk itu, dalam upaya memperoleh citra yang positif di masyarakat, hendaknya pelaksanaan pembangunan harusnya bersifat pembaharuan yang memihak terhadap masyarakat.

Program pembangunan daerah yang demokratis dilandasi oleh tiga pilar utama yang saling berkaitan. Ke tiga pilar ini adalah institusi pemerintah, institusi persdan masyarakat. Pers tidak akan berjalan secara signifikan apabila masyarakat tidak memiliki peranan. Sehingga pemerintah daerah akan sulit untuk mengetahui program apa yang diperlukan oleh masyarakat. Berdasarkan data dari Kementerian Dalam Negeri Republik Indonesia Tahun 2019, Provinsi Bali masuk ke dalam 10 besar provinsi dengan laju pertumbuhan perekonomian yang cukup tinggi. 
JURNAL ILMIAH MUQODDIMAH: Jurnal IImu Sosial, Politik Dan Humaniora E-ISSN : 2598-6236

http://jurnal.um-tapsel.ac.id/index.php/muqoddimah
Sosialisasi Kebijakan Pemerintah Provinsi Bali Melalui Perspektif Komunikasi Pembangunan.

(Putu Ika Astiti Tajem, I Nyoman Subanda)

Pada saat ini, Bali mengalami musibah dengan penularan pandemi Covid-19. Berdasarkan data Peta Penyebaran Covid-19 dari Tim SPBE Provinsi Bali. Dijelaskan bahwa grafik penyebaran Covid-19 di Bali terus meningkat secara tajam.

Untuk mencegah penularan Covid-19 lebih luas di Bali. Pemerintah Provinsi Bali mengeluarkan Pergub No.15 Tahun 2020 mengenai Paket Kebijakan Percepatan dalam Penanganan Corona Virus Disease 2019 (Covid-19) di Provinsi Bali. Kelompok Kerja Gugus Tugas Percepatan Penanganan Covid-19 Provinsi Bali menerapkan beberapa syarat medis seperti surat keterangan negatif rapid tes Covid-19 untuk memasuki wilayah Provinsi Bali.

Pemeriksaan para pelaku perjalanan yang masuk ke Bali dibantu oleh Satuan tugas Gotong Royong yang ada di masing - masing desa adat yang dibantu aplikasi Cek Diri yang berbasis website dan terintegrasi dengan Desa Adat. Sistem pemeriksaan ini membuat para pelaku perjalanan akan tetap menjalani prosedur sesuai dengan ketentuan yang berlaku. Bahkan apabila para pelaku perjalanan tidak memenuhi persyaratan, maka akan dapat kembali dipulangkan.

Untuk mempermudah dalam pengecekan pendatang yang masuk ke Bali yang melakukan penyebera-ngan atau pendatang wajib mendaftar-kan diri ke aplikasi pada website dengan alamat website yaitu https://cekdiri.baliprov.go.id/ yang telah disediakan oleh Pemerintah Provinsi Bali. Dalam aplikasi tersebut para pelancong atau traveler akan mengisi pada formulir dalam aplikasi tersebut untuk desa adat yang menjadi tujuan, sehingga Satgas Gotong Royong pada setiap Desa Adat dapat langsung memonitor pergerakan dari pelancong yang akan memasuki daerahnya melalui sistem Satgas Desa yang telah disediakan.

Aplikasi Cek Diri yang dibuat oleh Dinas Komunikasi, Informatika, dan Statistik Provinsi Bali ini berbasis Desa Adat sehingga data para pelaku perjalanan akan langsung tersampaikan ke Satgas Gotong Royong di setiap Desa Adat yang merupakan tempat tujuan perjalanannya.

Setiap pelancong juga akan langsung diketahui apakah sudah atau belum melengkapi diri dan mengisi aplikasi saat tiba di Bali sesuai dengan persyaratan yang telah ditentukan atas dasar Surat Edaran yang telah di tetapkan. Dengan sistem tersebut nantinya akan dipastikan untuk data diri pendatang, pekerjaannya, alamat tempat tinggal hingga pergerakan para pelaku perjalanan tersebut.

Melihat dari penjelasan diatas, jika dilihat dari kondisi riil, Provinsi Bali yang terdiri atas masyarakat yang heterogen dengan karakteristik, budaya dan adat istiadat yang berbeda. Hal ini menyebabkan tidak semua masyarakat mendapatkan informasi yang sama mengenai proses sosialisasi suatu kebijakan. Sehingga diperlukan model komunikasi yang berbeda untuk keberhasilan pembangunan dalam upaya memperoleh partisipasi masyarakat tersebut.

Model komunikasi yang digunakan dalam penelitian ini adalah komunikasi pembangunan. komunikasi pembangunan adalah usaha yang terorganisir untuk menggunakan proses komunikasi dan media dalam meningkatkan taraf sosial dan ekonomi yang secara umum berlangsung dalam negara sedang berkembang (Bulamei, et, al, 2017). Penelitian sebelumnya menyatakan bahwa komunikasi pembangunan dalam mengsosialiasikan suatu kebijakan mempunyai pengaruh yang sangat signifikan terhadap proses implementasi kebijakan tersebut (Susanto, 2016) dan (Suherman, 2017).

\section{METODE}

Dalam Penelitian ini menggunakan pendekatan kualitatif dan lokasi penelitian pada Pemerintah Provinsi Bali. Penelitian ini akan memilih salah satu OPD di Dinas Komunikasi, Informatika dan Statistik Pemerintah Provinsi Bali dengan alasan terdapat sumber data dan bahan yang lengkap dalam penelitian ini, khususnya yang berhubungan dengan Aplikasi Cek Diri.

Dalam penelitian ini untuk mendapatkan data dan informasi peneliti menggunakan beberapa teknik pengumpulan data seperti wawancara, dokumentasi, dan Teknik observasi. Wawancara Menurut Moleong dalam (Haris, 2011). Selanjutnya, dokumentasi Menurut 
JURNAL ILMIAH MUQODDIMAH: Jurnal IImu Sosial, Politik Dan Humaniora E-ISSN : 2598-6236

http://jurnal.um-tapsel.ac.id/index.php/muqoddimah
Sosialisasi Kebijakan Pemerintah Provinsi Bali Melalui Perspektif Komunikasi Pembangunan.

(Putu Ika Astiti Tajem, I Nyoman Subanda)

Herdiansyah dalam (Haris, 2011) "Dokumentasi merupakan salah satu cara yang dapat dilakukan peneliti kualitatif untuk mendapatkan gambaran dari sudut pandang subjek melalui suatu media tertulis dan lainnya yang ditulis atau dibuat langsung oleh subjek yang bersangkutan". Informan dalam penelitian ini ditentukan dengan menggunakan teknik Purposive Sampling (Sugiyono, 2016).

Analisis data yang di gunakan di dalam penelitian ini adalah analisis model interaktif yang dikemukankan oleh Miles dan Huberman dalam (Haris, 2010), terdiri dari : pengumpulan data (data collection) yaitu peneliti telah melakukan pemilihan tema pada awal penelitian; reduksi data (data condensation) yaitu proses penggabungan data yang telah diperoleh menjadi satu tulisan yang nantinya akan dianalisis kembali; display data (data display) yaitu mengolah data setengah jadi yang sudah seragam dalam bentuk tulisan dan sudah memiliki alur tema yang jelas; dan kesimpulan/verifikasi (conclusions: drawing/verifying) yang merupakan tahap terakhir dalam rangkaian analisis data kualitatif.

\section{HASIL DAN PEMBAHASAN}

Satuan Gugus Tugas (Satgas) Covid-19 Provinsi Bali merupakan Satuan Gugus Tugas yang dibentuk oleh Pemerintah Provinsi Bali yang bertujuan untuk menyikapi penyebaran virus Covid-19. Pemerintah Provinsi Bali bersama dengan pemangku kepentingan terkait secara signifikan berkoordinasi untuk melakukan Gerakan preventif sebagai upaya pencegahan penyebaran virus Covid-19. Pada saat ini, Gubernur Bali telah membentuk Satuan Tugas (Satgas) Penanggulangan Corona Virus Disease (Covid-19) yang disampaikan dalam Keputusan Gubernur Bali Nomor: 236/03-B/HK/2020 tanggal 10 Maret 2020. Satgas dipimpin oleh Sekretaris Daerah Provinsi Bali. Satuan tugas tersebut meliputi : 1) Satuan Tugas Kesehatan; 2) Satuan Tugas Area dan Transportasi Publik; 3) Satuan Tugas Area Institusi Pendidikan; 4) Satuan Tugas Komunikasi Publik; dan 5) Satuan Tugas Pintu Masuk Indonesia. Satuan tugas (Satgas) tersebut bertugas untuk menyelenggarakan kewaspadaan dan penanggulangan penyebaran Covid-19 secara menyeluruh dan melaporkan perkembangan Covid-19 setiap hari. Serta melaksanakan protokol penanggulangan Covid-19 dan melaporkan perkembangannya setiap hari kepada Gubernur.

Dalam pelaksanaan tugas, Satuan tugas (Satgas) mematuhi protokol yang telah ditetapkan oleh pemerintah. Satuan tugas tersebut meliputi protokol area publik dan transportasi khususnya pintu masuk Indonesia, protokol komunikasi, area pendidikan, dan protokol kesehatan. Seluruhnya mengacu pada protokol yang ditentukan oleh pemerintah pusat. Pada saat ini, lima yang diprioritaskan dan harus segera dilaksanakan oleh Satgas Covid-19 ialah sebagai berikut:

1. Peningkatan kapasitas dalam penanganan penyakit, khususnya peningkatan sarana prasarana fasilitas kesehatan, seperti rumah sakit. Fasilitas kesehatan tersebut harus memiliki kapasitas yang memadai untuk mengantisipasi peningkatan angka penyebaran Covid-19 di Bali. Memastikan fasilitas kesehatan (faskes) memiliki kapasitas ruang isolasi dengan jumlah yang mencukupi dan sesuai dengan standar. Serta para tenaga medis yang memiliki kualifikasi harus dipastikan jumlahnya. Agar dapat mengantisipasi peningkatan pelayanan. Ketersediaan fasilitas Kesehatan dengan dukungan tim medis yang siap tanggap akan membangun kepercayaan masyarakat terhadap penanganan Covid-19.

2. Memastikan ketersediaan alat pelindung diri (APD) yang diperlukan untuk pencegahan dan penularan Covid-19 seperti masker, hand sanitizer dan antiseptik. Memastikan jumlah ketersediaan barang tersebut, agar tidak menimbulkan kepanikan bagi masyarakat.

3. Meningkatkan pencegahan penularan Covid-19 di wilayah pintu masuk daerah, seperti bandara dan pelabuhan.

4. Pengendalian penyebaran Covid-19 dengan melakukan pembatasan kegiatan yang melibatkan banyak orang atau masa. 
5. Melaksanakan kampanye pola Perilaku Hidup Bersih dan Sehat (PHBS). Kepala daerah diupayakan untuk membuat video durasi pendek yang bertujuan untuk memberikan informasi dan sosialisasi kepada masyarakat terkait Covid-19 dan pencegahannya.

Dinas Komunikasi, Informatika, dan Statistik Provinsi Bali dalam upaya mendukung pencegahan dan penanggulangan Covid-19 membuat aplikasi layanan informasi publik Cek Diri: https://cekdiri.baliprov.go.id/ dimana database dalam website ini langsung terhubung dengan Satgas Gotong Royong yang ada di setiap wilayah pada Desa Adat di Bali.

Di sini setiap masyarakat atau para pelaku perjalanan baik pelaku perjalanan dalam negeri maupun pelaku perjalanan luar negeri yang akan masuk wilayah Bali melalui pelabuhan Gilimanuk, Padang Bay dan Bandara Internasional I Gusti Ngurah Rai, sebelumnya hanya harus mengecek pos pemeriksaan kartu tanda penduduk. Namun, pada saat ini diwajibkan para pelaku perjalanan diwajibkan untuk memahami dan mengisi form aplikasi Cek Diri. Hal ini sangat penting dilaksanakan, yang bertujuan untuk memantau pergerakan dan kondisi pelaku perjalanan tersebut. Apabila terjadi sesuatu, penanganan pun akan cepat dilaksanakan dan ditindaklanjuti.
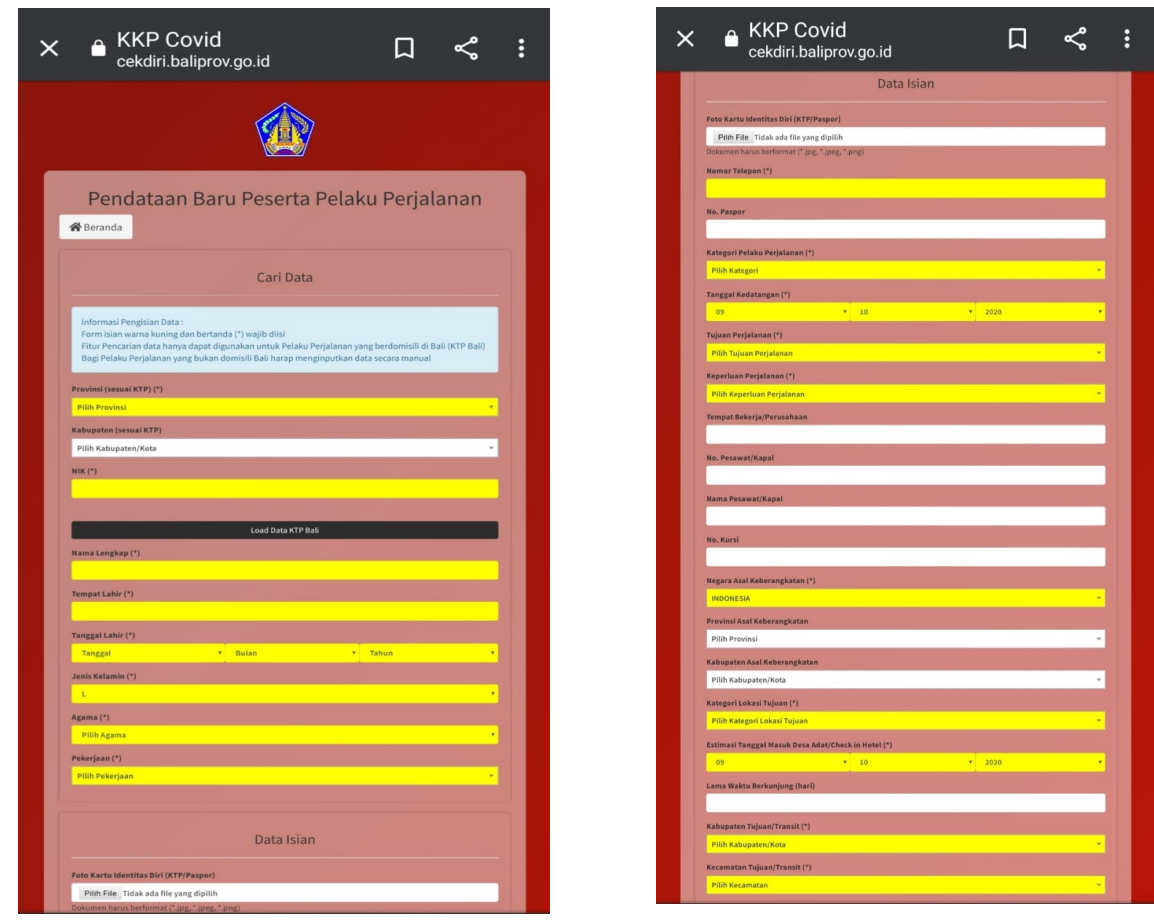

Gambar 1 Tampilan aplikasi Cek Diri pada Smart Phone

Para pelaku perjalanan baik dalam negeri maupun pelaku perjalanan luar negeri wajib mengisi data dalam formulir aplikasi 'Cek Diri'. Dengan mengisi aplikasi dapat memastikan data diri, pekerjaan, tempat tinggal hingga pergerakan para pelaku perjalanan yang berkunjung ke Bali, karena informasi tersebut terintegrasi puladengan Satgas gotong-royong Desa Adat di wilayah Bali. Petugas pada Desa Adat juga nantinya akan selalu memastikan pelancong tersebut untuk melakukan Standar Operasional Prosedur seperti pelaksanaan protokol kesehatan Covid-19 dan isolasi diri.

Untuk mendukung sosialisasi pengisian aplikasi Cek Diri kepada para pelaku perjalanan dalam negeri dan luar negeri, Dinas Komunikasi, Informatika dan Statistik Provinsi Bali melaksanakan piket jaga di pintu gerbang masuk Pulau Bali. Baik di Pelabuhan Gilimanuk atau Padang Bay maupun di Bandara Internasional Ngurah Rai. 
JURNAL ILMIAH MUQODDIMAH: Jurnal IImu Sosial, Politik Dan Humaniora E-ISSN : 2598-6236

http://jurnal.um-tapsel.ac.id/index.php/muqoddimah
Sosialisasi Kebijakan Pemerintah Provinsi Bali Melalui Perspektif Komunikasi Pembangunan.

(Putu Ika Astiti Tajem, I Nyoman Subanda)

Sosialisasi suatu kebijakan akan dapat berjalan dengan efektif apabila para pelaksana kebijakan memiliki pengetahuan akan suatu kebijakan yang dilaksanakan. Pada penelitian ini, pengetahuan informan terkait sosialisasi kebijakan Pemerintah Provinsi Bali dalam Perspektif Komunikasi Pembangunan menggunakan lima unsur komunikasi yang saling bergantung satu sama lain yang dirumuskan oleh Lasswell, yaitu: komunikator (communicator, source, sender, encoder), pesan (massage), media (channel), komunikan (communica-nt, communicatee, receiver, recipient, de-coder), dan efek (effect, impact, influe-nce).

Pesan yang disampaikan disampaikan kepada para pelaku perjalanan baik pelaku perjalanan dalam negeri maupun luar negeri ialah berupa ajakan dan himbauan dalam penggunaan aplikasi Cek Diri manfaat dan keuntungaan penggunaan dari aplikasi ini. Pesan tersebut disampaikan secara rutin dan berulang kepada masyarakat pelaku perjalanan, baik di wilayah Bandara Internasional I Gusti Ngurah Rai maupun di Pelabuhan Gilimanuk atau Padang Bay. Ini merupakan pintu gerbang Bali. Di lapangan sudah disiapkan petugas dari Diskominfos Prov. Bali yang bertugas untuk mengarahkan para pelaku perjalanan mengisi Aplikasi Cek Diri tersebut. Selain itu, pemerintah Provinsi Bali juga bekerjasama dengan beberapa media baik itu yang berbentuk media cetak, elektronik, maupun media online untuk mensosialisasikan berbagai kebijakan Pemprov. Bali guna menunjang percepatan penanganan Kesehatan terkait Covid-19.

Pada masa pandemic Covid-19 identitas diri, Kartu Pendatang (Kipem), surat keterangan dari tempat bekerja hingga surat keterangan yang menyatakan bebas Covid-19 merupakan syarat utama atau acuan bagi para pelaku perjalanan untuk masuk ke Bali. selain itu, Pemerintah Provinsi Bali juga mengharuskan para pelaku perjalanan yang akan masuk ke Bali untuk mengisi aplikasi Cek Diri. Para petugas dari Pemprov berjaga di Pelabuhan Gilimanuk atau Padang Bay dan Bandara Internasional I Gusti Ngurah Rai untuk dapat memastikan data diri, dimana bekerja, dan alamat tempat tinggal hingga pergerakan para pelaku perjalanan yang berkunjung ke Bali, karena terhubung dengan Satgas gotong-royong Desa Adat di seluruh wilayah Bali. Satgas Desa Adat ini nantinya akan memastikan para pelaku perjalanan tersebut apakah sudah melakukan Standar Operasional Prosedur seperti pelaksanaan protokol kesehatan Covid-19 dan isolasi diri.

Dalam sosialisasi aplikasi Cek Diri, Dinas Komunikasi, Informatika, dan Statistik Provinsi Bali melaksanakan kerjasama dan perjanjian dengan beberapa media massa. Baik itu media cetak dan elektronik, maupun media online.Pemerintah Provinsi Bali melalui Dinas Komunikasi, Informatika, dan Statistik Provinsi Bali bekerjasama dengan beberapa media cetak dan elektronik menangani permasalahan Covid-19 dengan aplikasi Cek Diri, yaitu : Denpost, Nusa Bali, Radar Bali, Pos Bali, Fajar Bali, Tribun Bali, Warta Bali, Koran Metro, Nuansa Bali, Bali Kini, Dialog, Tokoh, Bali Kini, Dialog, Tokoh, Bisnis Bali, Bali Travel News, Bali Tribun, Bali Post, dan Bali Ekspress. Sedangkan media elektronik (televisi) yang bekerjasama dengan Pemerintah Provinsi Bali yaitu LPP TVRI Bali, Bali TV, INews TV Bali, dan Kompas Dewata TV, selain media elektronik televisi, Pemerintah Provinsi Bali melalui Dinas Komunikasi, Informatika, dan Statistik Provinsi Bali juga bekerjasama dengan media elektronik radio seperti : Radio Gema Merdeka, Radio Gita Bakti Persada (Phoenix) Denpasar, Radio Pinguin Denpasar, Radio Duta Fm, Radio Gema Sunari Indah (Suara Sunari), Radio Suara Denpasar Chakti (Cassanova), Radio Republik Indonesia (RRI) Denpasar, dan beberapa radio yang ada di Kabupaten/Kota di Bali. Aplikasi Cek Diri yang bertujuan untuk penanganan para pelaku perjalanan yang akan masuk ke Bali. Dinas Komunikasi, Informatika dan Statistik Provinsi Bali juga membuat spot iklan di radio yang diharapkan dapat membantu warga untuk mengetahui informasi mengenai aplikasi Cek Diri. Spot iklan ini dibuat simple dan mudah dipahami oleh pendengar radio.

Pemerintah Provinsi Bali melalui Dinas Komunikasi, Informatika, dan Statistik juga bekerjasama dengan beberapa media online, melalui akun media resmi, seperti akun website resmi Pemerintah Provinsi Bali, akun Instagram resmi Pemerintah Provinsi Bali, dan akun facebook resmi Pemerintah Provinsi Bali. Seluruh akun media resmi pemerintah dikelola 
langsung oleh Dinas Komunikasi, Informatika, dan Statistik Provinsi Bali dan diawasi langsung oleh Gubernur Bali, Wakil Gubernur Provinsi Bali dan Sekretaris Daerah Provinsi Bali.

Hasil dari rekapitulasi data aplikasi Cek Diri tersebut akan langsung terhubung dengan Satgas Gotong Royong yang ada di masing - masing Desa Adat di wilayah Provinsi Bali. Sehingga dapat mempermudah Pemerintah dan Desa Adat untuk mendata para pelaku perjalanan yang masuk ke wilayahnya. Dengan penggunaan aplikasi Cek Diri di Pelabuhan Gilimanuk atau Padang Bay dan Bandara Internasional I Gusti Ngurah Rai akan mempermudah Satgas Gotong Royong Desa Adat mendata jumlah pelaku perjalanan yang masuk ke wilayahnya. Sehingga dapat mengantisipasi segala kemungkinan yang dapat terjadi apabila para pelaku perjalanan tersebut terpapar Covid-19.

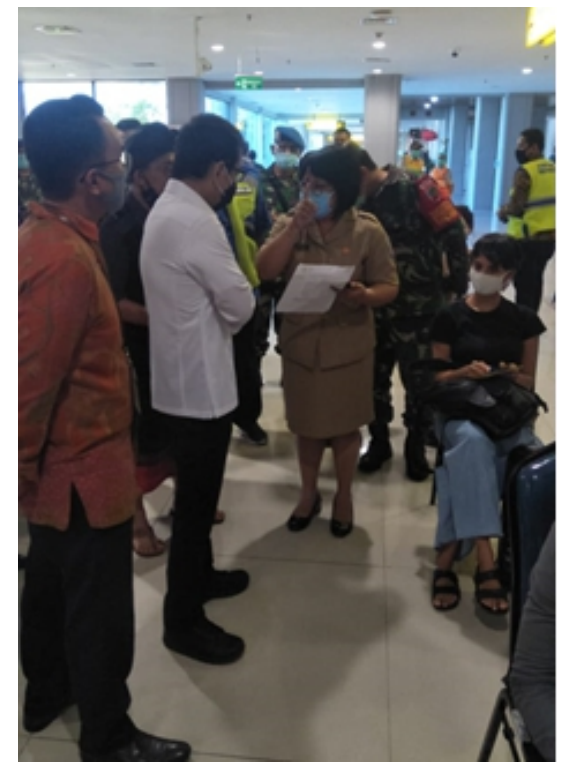

Gambar 2. Menteri Pariwisata dan Ekonomi Kreatif RI mengisi Aplikasi Cek Diri di Bandara Internasional I Gusti Ngurah Rai, tanggal 16 Juni 2020 (Sumber Diskominfos Provinsi Bali)

Dalam komunikasi Pemerintah Provinsi Bali melalui Dinas Komunikasi, Informatika dan Statistik Provinsi Bali dalam upayanya untuk mencegah penyebaran Covid-19. Pemerintah Provinsi Bali membentuk suatu pola sosialisasi yang merupakan sistem dalam proses kehidupan masyarakat yang sangat vital, yaitu melalui aplikasi Cek Diri. Berdasarkan hal tersebut, maka sosialisasi memberikan dua kontribusi fundamental bagi kehidupan masyarakat pada masa pandemi Covid-19 pada saat ini, yaitu:

1. Memberikan pemahaman kepada individu agar terciptanya partisipasi yang efektif dalam masyarakat, khususnya pada penanggulangan Covid-19. Dimana pada saat ini, Pemerintah Provinsi Bali melalui Dinas Komunikasi, Informatika dan Statistik Provinsi Bali menciptakan inovasi berupa aplikasi Cek Diri di masa pandemi Covid-19. Dimana aplikasi tersebut dapat mempermudah Pemerintah untuk mendata para pelaku perjalanan yang akan masuk ke wilayah Bali. Pemerintah berupaya menciptakan Aplikasi ini diciptakan mengikuti perkembangan jaman digital dan saat ini sangat efektif di masyarakat.

Memungkinkan kepercayaan suatu masyarakat karena tanpa adanya sosialisasi maka akan hanya ada satu kalster saja hingga kepercayaan masyarakat tersebut akan terganggu. Dengan adanya aplikasi Cek Diri, pemerintah berupaya mensosialisa-sikan dan membantu para pelaku perjalanan agar tetap merasa aman dan nyaman apabila berkunjung ke Bali. Selain itu, Satgas Gotong Royong Desa Adat pun akan sangat terbantu dengan penggunaan aplikasi Cek Diri. Aplikasi Cek Diri yang berbasis Desa Adat ini menyampaikan data para pelaku perjalanan ke Satgas Gotong Royong di seluruh Desa Adat yang merupakan tujuan dari pada pelancong. 
JURNAL ILMIAH MUQODDIMAH: Jurnal IImu Sosial, Politik Dan Humaniora E-ISSN : 2598-6236

http://jurnal.um-tapsel.ac.id/index.php/muqoddimah
Sosialisasi Kebijakan Pemerintah Provinsi Bali Melalui Perspektif Komunikasi Pembangunan.

(Putu Ika Astiti Tajem, I Nyoman Subanda)

Setiap pelaku perjalanan juga akan diketahui sudah memper-siapkan dirinya saat tiba di Bali sesuai prasyarat yang ditetapkan atas dasar surat edaran yang sudah di tentukan. Sehingga kelestarian di masyarakat Bali akan tetap terjaga dengan tetap melibatkan Desa Adat dalam penanggulangan Covid-19.

\section{SIMPULAN DAN SARAN}

Untuk mencegah perkembangan dan penularan Covid-19 lebih luas di Bali. Pemerintah Provinsi Bali mengeluarkan Pergub No.15 Tahun 2020 yang mengenai Paket Kebijakan Percepatan Penanganan Corona Virus Disease 2019 (Covid-19) di Provinsi Bali. Pihak Gugus Tugas Percepatan dalam Penanganan Covid-19 Provinsi Bali menerapkan prasyarat medis seperti surat keterangan negatif rapid tes Covid-19 bahkan juga surat keterangan swab tes untuk memasuki wilayah Provinsi Bali.

Pemeriksaan para pelaku perjalanan atau pendatang dibantu oleh Satgas Gotong Royong yang ada di setiap desa adat sebagai serta dibantu oleh aplikasi Cek Diri berbasis website yang teritegrasi dengan Desa Adat. Pendatang wajib mendaftarkan diri ke website https://cekdiri.baliprov.go.id

Hasil penelitian menunjukan strategi komunikasi yang dilaksanakan dalam sosialisasi aplikasi Cek Diri dilakukan dengan sosialisasi di lapangan yang dibantu oleh petugas piket Dinas Komunikasi, Informatika, dan Statistik Provinsi Bali serta beberapa petugas dari OPD terkait yang bertempat di Bandara Internasional I Gusti Ngurah Rai dan Pelabuhan Gilimanuk ataupun Padang Bay. Serta menyebar-kan pesan dalam berbagai bentuk yang disesuaikan dengan media yang digunakan oleh Pemerintah Provinsi Bali.

\section{DAFTAR PUSTAKA}

Andika, D. (2012). Pembangunan Masyarakat Dan Kesejahteraan Sosial Dalam Perspektif Komunikasi Pembangunan. Proseding Seminar Nasional FISIP-UT.

Bappeda Litbang Provinsi Bali. 2019. Materi Arahan Menteri Dalam Negeri dalam Acara Pembukaan Musyawarah Rencana Pembangunan RKPD Provinsi Bali Tahun 2020

Bulamei, Elisabet Christin. Ferry V.I.A Koagouw. Anita Runtuwene (2017). Kajian Komunikasi Pembangunan Dinas Pekerjaan Umum Dalam Meningkatkan Perbaikan Infrastruktur Kota Manado. Jurnal Acta Diurna Komunikasi. Vol 6 No 3.

Munandar, Harris. Suherman, Maman. (2016). Aktivitas Komunikasi Pemerintahan Ridwan Kamil di Media Sosial. Prosiding Hubungan Masyarakat UNISBA. Vol. 2 No. 1.

Pemerintah Provinsi Bali. (2018). Visi dan Misi Provinsi Bali.

Pemerintah Provinsi Bali. (2020). Peraturan Gubernur Bali Nomor 15 Tahun 2020 Tentang Paket Kebijakan Percepatan Penanganan Corona Virus Disease 2019 (Covid-19) Di Provinsi Bali.

Susanto, Eko Harry. (2017). Kelambanan Reformasi Birokrasi dan Pola Komunikasi Lembaga Pemerintah. Availabel Jurnal Aspikom. Vol 1 No 1

Suwardani, Ni Putu. (2015). Pewarisan Nilai-nilai Kearifan Lokal untuk Memproteksi Masyarakat Bali dari Dampak Negatif Globalisasi. Jurnal Kajian Bali. Vol 5 No 2

Syarif, Jamal. (2017). Sosialisasi Nilai-Nilai Kultural Dalam Keluarga Studi Perbandingan SosialBudaya Bangsa-Bangsa. Jurnal Kajian Budaya. Vol 7 No1

Undang - Undang Nomor 14 Tahun 2008 tentang Keterbukaan Informasi Publik. 2017. Denpasar: PPID Provinsi Bali

Yusuf, Iwan Awaluddin. (2011). Media Lokal dalam Konstelasi Komunikasi Politik di Daerah. Jurnal IImu Sosial dan Politik. Vol 14 No. 3. 